\title{
Questes
}

vestes Revue pluridisciplinaire d'études médiévales

\section{Le « chalivali » du Roman de Fauvel : bruit ou musique?}

\section{Agathe Sultan}

\section{(2) OpenEdition}

1 Journals

\section{Édition électronique}

URL : http://journals.openedition.org/questes/2349

DOI : 10.4000/questes.2349

ISSN : 2109-9472

Éditeur

Les Amis de Questes

\section{Édition imprimée}

Date de publication : 15 mars 2003

Pagination : 15-16

ISSN : 2102-7188

\section{Référence électronique}

Agathe Sultan, «Le " chalivali » du Roman de Fauvel : bruit ou musique? », Questes [En ligne], 3 | 2003, mis en ligne le 01 janvier 2014, consulté le 19 septembre 2020. URL : http://journals.openedition.org/ questes/2349; DOI : https://doi.org/10.4000/questes.2349

Ce document a été généré automatiquement le 19 septembre 2020.

(c) Association des amis de «Questes » 


\title{
Le « chalivali » du Roman de Fauvel : bruit ou musique?
}

\author{
Agathe Sultan
}

NOTE DE L'ÉDITEUR

Cet article n'a pas encore fait l'objet d'une autorisation de publication.

INDEX

Mots-clés : bruit, ville, musique, charivari, vacarme, Fauvel

Keywords : noise, city, music, charivari, din, Fauvel 